\title{
Clinical Symptoms and Histological Changes in Poecilia reticulata following Gamma-Rays Irradiation
}

\author{
K. BEŇOVÁ ${ }^{1}$, V. CIGÁNKOVÁ ${ }^{1}$, M. FALIS ${ }^{1}$, B. ŠMAJDA ${ }^{2}$ \\ ${ }^{1}$ University of Veterinary Medicine, Košice, Slovakia \\ ${ }^{2}$ Faculty of Science, P.J. Šafárik University, Košice, Slovakia \\ Received March 13, 2006 \\ Accepted June 30, 2006
}

\begin{abstract}
Beňová K., V. Cigánková, M. Falis, B. Šmajda: Clinical Symptoms and Histological Changes in Poecilia reticulata following Gamma-Rays Irradiation. Acta vet. Brno 2006, 75 : 557-560.

Lethality, food intake, clinical symptoms and terminal histological changes were followed after gamma-irradiation with doses of 10, 20,30, 35 and 40 Gy in guppy, Poecilia reticulata. Clinical symptoms, food intake and longevity were also monitored in the progeny of fish irradiated with a dose of $10 \mathrm{~Gy}$.

In the first days after irradiation timidity and lethargy were observed. After doses of 30, 35 and $40 \mathrm{~Gy}$, these symptoms were accompanied with anorexia. The most prominent clinical symptoms observed were emaciation, hampered breathing, exophthalmia and haemorrhages. Histological findings corresponded with these symptoms. In the fish irradiated with 10 or 20 Gy the progeny survived, after a dose of 30 Gy the progeny died within 24 hours after birth and after doses of 35 and 40 Gy dead progeny was born. The survival data provide an estimate of $\mathrm{LD}_{50 / 30}$ equal to 29 Gy. Higher relative mortality and more severe clinical symptoms were observed in females. The progeny of irradiated parent fish grew and survived for 3 months maximum.
\end{abstract}

Guppy, gamma irradiation, lethality, clinical symptoms, morphological changes

Ionizing radiation represents one of the universal components of the environment. Humans and animals are permanently exposed to ionizing radiation from external and internal sources (Dvořák et al. 2005). During hundreds of millions years of phylogenesis animals developed adaptive mechanisms enabling them to survive in an environment with a radiation background. In approximate estimate it may be said that the lower the phylogenetic stage of a species, the higher is its resistance to harmful effects of radiation (Beňová et al. 2001; Dvořák and Beňová 2002; Škardová et al. 1994).

In the past, the prevailing part of the radiobiological research was done on mammals and birds; the radiation effects on fish were not studied in a comparable extent. Recently, some alternative biomedical models have been used in the study of radiation effects on animals (Dvořák and Šucman 1996; Dvořák and Beňová 2002). Guppies (Poecilia reticulata) and the species Danio rerio, often bred in home aquaria as undemanding species have found broad application as experimental animals, too (Lešník and Jurčina 1994).

\section{Materials and Methods}

In the experiments guppies (Poecilia reticulata) were used from a laboratory breed established two years before from fish bred specially for laboratory purposes. The breed had been kept under constant conditions: water temperature of $24^{\circ} \mathrm{C}, \mathrm{Ca}+\mathrm{Mg}$ concentration of $0.7 \mathrm{mmol} / \mathrm{l}, \mathrm{pH}=7.04$, artificial aeration, water filtration, light regimen LD 12:12 hours (Procházka and Dvořák 2002). The fish were fed with live, flocked or granulated food.

Experimental fish picked at random and divided into experimental groups were kept under the same conditions as described above. There were 16 fish in each experimental group ( 8 males and 8 females), living in an aquarium with a volume of 10 litres. During the experiment the fish were fed a flocked food mixture (AQUA EXOTIC, Kapušany, Slovakia). 
During 30 days after irradiation the changes of behaviour and other possible pathological symptoms, mainly changes on the body surface observable by naked eye, and lethality were recorded (Dvořák 2004). The results were compared with the control group. Lethal concentrations were calculated by means of the ML method of probit analysis, which enables to calculate the confidence interval for 95\% probaility (Litchfield and Wilcoxon 1949). The results were completed with histological analyses.

The guppies were irradiated with doses of $10,20,30$ and $40 \mathrm{~Gy}$ of gamma-rays from a ${ }^{60} \mathrm{Co}$ source (CHISOSTAT apparatus, Chirana, Prague, Czech Republic) with a dose rate of $11.36 \mathrm{~Gy} / \mathrm{min}$. In contrast to claims of OECD, gravid females were irradiated, too. The fish were irradiated in Petri dishes $(\varnothing 9 \mathrm{~cm})$ filled with aquarium water to $1 \mathrm{~cm}$ of the water column. The controls were sham-irradiated.

Samples for histological analysis were processed by commonly used methods. Whole fish were fixed in a $3 \%$ of neutral formaline solution and mounted in paraffin. Histological slices of $7 \mathrm{~mm}$ thickness were stained with hematoxylin-eosin and microscopically evaluated.

The progeny of fish irradiated with $10 \mathrm{~Gy}$ was displaced after finishing the 30-day period after irradiation into an aquarium with a volume of 501 , where the clinical symptoms, food intake and longevity were observed. They were compared with age-matched controls. The whole experiment was repeated two times.

\section{Results}

In the first days after irradiation the fish were timid and lethargic. After irradiation with higher doses they dwelled at the bottom of the aquarium. Their motions were uncoordinated. During the first week following irradiation the fish in all experimental groups stayed in shoal pressed together, which is atypical behaviour for this species.

The food intake was decreased in groups irradiated with doses of 20,30, 35 and 50 Gy (Table1). In the groups irradiated with 35 and $40 \mathrm{~Gy}$ a decrease in food intake was observed from the $10^{\text {th }}$ day after irradiation. The decrease of food intake led to marked emaciation.

The first macroscopically visible changes on the body of irradiated fish included bilateral exophthalmia, often preceded by eye haemorrhage. Haemorrhages began to appear approximately 8 to 12 days after irradiation in all irradiated groups on various parts of the body. The most severe haemorrhages were present in the region of gills. In the group irradiated with $10 \mathrm{~Gy}$ the haemorrhages were no more observed after the $17^{\text {th }}$ day after irradiation.

The fading out of the body colour was observed from the $10^{\text {th }}$ day. In the group irradiated with $10 \mathrm{~Gy}$ it was transient and lasted only 2 - 5 days. In other experimental groups it was present until the end of the observation on the $30^{\text {th }}$ day after irradiation. In the individuals that died during the observation period, a darkening of the skin was observed shortly before death.

In all experimental groups a withdrawal of fins was observed. After doses of 30, 35 and 40 Gy we observed convulsive broad opening of the mouth since the $7^{\text {th }}$ day. Three days before death the bodies of fish were oriented perpendicular to surface with mouths at the surface level.

Table 1. Comparison of food intake, birth of progeny and lethality after various radiation doses

\begin{tabular}{|c|c|c|c|}
\hline Dose [Gy] & Lethality [\%] & Birth of progeny & Food intake \\
\hline 10 & 0 & alive & rormal \\
\hline 20 & 10 (female-10) & alive & reduced \\
\hline 30 & $\begin{array}{c}50 \text { (female-30, } \\
\text { male-20) }\end{array}$ & alive, dead after 24 hours & reduced, decreased to zero \\
\hline 35 & $\begin{array}{c}80 \text { (female-60, } \\
\text { male-20) }\end{array}$ & all dead & reduced, decreased to zero \\
\hline 40 & 100 & all dead & \\
\hline
\end{tabular}

Lethality recorded in our experiments is given in Table 1 . The value of $\mathrm{LD}_{50 / 30}$ calculated from our results was $29 \mathrm{~Gy}$ with a confidence interval for $P<0.05$ ranging from 26 to $31 \mathrm{~Gy}$.

In groups irradiated with 10 or $20 \mathrm{~Gy}$ the progeny was born alive. After a dose of $30 \mathrm{~Gy}$ the progeny was born alive, too, but died within 24 hours (Table 1). 
A higher rate of lethality (Table 1) and more pronounced clinical symptoms (more widespread haemorrhages, more pronounced emaciation) were observed in females.

In the second part of the experiment we followed the progeny of fish irradiated with $10 \mathrm{~Gy}$. The food intake did not differ from controls. In all individuals of the experimental group retardation of growth in comparison with the control group was recorded. In some individuals a bending of the spinal column was observed. Marked shortening of the life span was recorded in the experimental group, where no individual survived longer than 3 months.

Histological findings

Figs. 1 and 2 (Plate III) show the comparison of the liver parenchyma of a control animal with the liver parenchyma of an animal 24 hours after irradiation with $30 \mathrm{~Gy}$. The hepatocytes in control animals were polyedric with a round nucleus at the centre of the cell, whereas the hepatocytes in the irradiated animals had stellar form and the nuclei were displaced eccentrically. Typically, lipid vacuoles were present in the liver of the irradiated animal. The blood vessels were filled with blood.

Fig. 3 (Plate IV) shows the mucous of the intestine 24 hours after irradiation with $30 \mathrm{~Gy}$. The intestinal villi were relatively low. The epithelium consisted of enterocytes of cylindrical to cubic shape. Low microvilli on their apical surface were present. On some sites delaminating of the epithelium occurred. There was homogenous material in the stroma of intestinal villi.

\section{Discussion}

In spite of the fact that the effects of ionizing radiation on the organisms of mammals and birds have been studied in detail, there is only a limited number of papers dealing with the effects of gamma-rays on the fish (Falis et al. 2004; Beňová et al. 2003; Škardová et al. 1994).

The results of these authors reveal that in comparison with domestic animals (mammals, birds), fish are much more radio-resistant (Procházka and Dvořák 2002).

An early reaction of mammals and birds to gamma-irradiation consists of bone marrow and haemorrhagic syndromes, manifested by oedemas and large haemorrhages (Procházka and Dvořák 2002).

We observed haemorrhages in various parts of the body in all experimental groups. The haemorrhages observed are identical to changes described by $\mathrm{Hršel} \mathrm{(1950)} \mathrm{as} \mathrm{inflammatory}$ processes on the skin of the fish, leading to death within 20 days.

Samochvalovova (1935) and Hršel (1950) described a transient fading out of the skin colour after irradiation with x-rays in Poecilia reticulata. The fading out in our experiments lasted approximately from the $10^{\text {th }}$ day after irradiation until the end of the experiment on the $30^{\text {th }}$ day.

We observed similar symptoms of lethargy, anorexia and marked emaciation, as it is typical for mammals and birds and as it was reported for Poecilia reticulata after irradiation with x-rays by Seidelová (1986).

Decreased food intake or food refusal was described also in mammals and birds as the symptoms of the gastrointestinal syndrome of radiation disease (Procházka and Dvořák 2002). Our histological findings correspond with these symptoms. The enteric villi compared with controls were relatively low. Enterocytes taking part in resorption processes were damaged, they desquamated on some sites and the number of microvilli on their surface was reduced. The decrease of microvilli number indicates malfunctioning of the intestinal resorption, which can lead to emaciation (Beňová et al. 2002).

We observed higher mortality and more pronounced clinical symptoms in females, contrasting to our earlier findings in mammals, where higher radiosensitivity in males was found (Beňová et al. 2001). 
The value of $\mathrm{LD}_{50 / 30}$ calculated from our data equals approximately to $30 \mathrm{~Gy}$. This is in accordance with the value after irradiation with x-rays given by Seidelová (1986).

\section{Klinické príznaky a histologické zmeny u Poecilia reticulata po ožiarení gama-lúčmi}

V našom experimente sme sledovali po dobu 30 dní letalitu, príjem potravy, klinické príznaky a následné histologické zmeny u rýb Poecilia reticulata po ožiarení dávkami 10, 20, 30, 35 a 40 Gy gama lúčov. Klinické príznaky, príjem potravy a dížku života sme tiež sledovali u potomstva rýb ožiarených dávkou 10 Gy.

$\mathrm{V}$ prvých dňoch po ožiarení sme u rýb pozorovali plachost̉ a malátnosti. Po ožiarení dávkami 30, 35 a 40 Gy aj znížený príjem potravy. Z klinických príznakov sme pozorovali vychudnutie, stažené dýchanie, exoftalmus a krvácaniny. Tomuto faktu zodpovedal aj histologický nález. U rýb ožiarených dávkami 10 a 20 Gy sa rodilo živé potomstvo. Po ožiarení dávkou 30 Gy sa rodilo živé potomstvo, ale uhynulo do 24 hodín. Po ožiarení dávkami 35 a 40 Gy sa rodilo mŕtve potomstvo.

$\mathrm{Na}$ základe našich výsledkov je dávka LD ${ }_{50 / 30} 29$ Gy. Vyššie percento úhynu a výraznejšie klinické príznaky sme pozorovali u samíc.

Potomstvo ožiarených rodičov zaostávalo v raste a dožívalo sa veku najviac 3 mesiace.

\section{Acknowledgements}

The study was supported by the grant VEGA No. 1/2358/05. The authors wish to thank for financial support of the project.

\section{References}

BEŇOVÁ K, TOROPILA M, FALIS M, PALUCHOVÁ K, NOVÁKOVÁ J 2001: Effect of ionizing radiation on the organism - in relation to dose, species, sex and age. Actual Questions of Animal Bioclimatology. VFU Brno, p. 10-11.

BEŇOVÁ K, FALIS M, TOROPILA M, SEHNALKOVÁ H, PASTVOVA L 2002: Influence of a single $\gamma$-irradiation on rat microflora. Folia Microbiol 47: 461-462

BEŇOVÁ K, TOROPILA M, FALIS M, DVOŘÁK P 2003: Influence of Ionising Radiation on the Activity of Selected Adaptive Enzymes in Chickens and Rats. Acta Vet Brno 72: 201-205

ČSN 466807 1974. Acute toxicity test on fishes, 7 p.

DVOŘ́K P, ŠUCMAN E 1996: Instructions for Practical Lessons on Biophysics and Basics of Statistics (In Czech). VFU Brno, 44 p.

DVOŘ́K P, BEŇVÁ K 2002: An investigation of the interactions of low doses of ionising radiation and risk factors by means of the Artemia salina biotest. Folia Vet 46: 195-197

DVOŘ́́K P 2004: Selected specificity of Aquarium fish disease. Bulletin VÚRH Vodňany 40: 101-108

DVOŘ́K P, KRATOCHVÍL B, GROLICHOVÁ M 2005: Changes of colour and pH in fish musculature after ionizing radiation exposure. Eur Food Res Technol 220: 309-311

FALIS M, BEŇOVÁ K, TOROPILA M, SESZTÁKOVÁ E, LEGÁTH J 2004: Changes in the activity of selected adaptive enzymes in chicken liver after single gamma irradiation. Bull Vet Inst Pulawy 48: 503-506

HRŠEL I 1950: The Effect of X-rays on Spermatogenesis of Lebistes reticulates. Univerzitní knihovna Praha, $134 \mathrm{p}$.

LEŠNIKK F, JURČINA A 1994: Model system-fishis. Veterinářství 2: 77

LITCHFIELD JT, WILCOXON F 1949: A simplified method of evaluating dose-effect experiment. J Pharmacol 96: $96-113$

OECD Guideline for testing of chemicals, Adopted by the Council on $17^{\text {th }}$ July 1992 . Fish, Acute Toxicity Test, $9 \mathrm{p}$.

PROCHÁZKA Z, DVOŘÁK P 2002: Veterinary Radiobiology and Radiation Hygiene. (In Czech) Veterinary and Pharmaceutical University, Brno, $125 \mathrm{p}$.

SAMOCHVALOVOVA GW 1935: Effect of X-rays on fishes. Biol J 7: 1023-1033

SEIDELOVÁ A 1986: Lethal effect of X-rays on penguin fish varieties Poecilia reticulata Peters and Brachydanio rerio. Radiobiologia 6: $820-822$

ŠKARDOVÁ I, OJEDA F, PROSBOVÁ M, ROSIVAL I 1994: Radiation induced disorders of hematopoiesis in chicken (Apoptosis). Folia Vet 38: 81-84 
Plate III

Beňová B. et al.: Clinical Symptons ... pp. 557-560

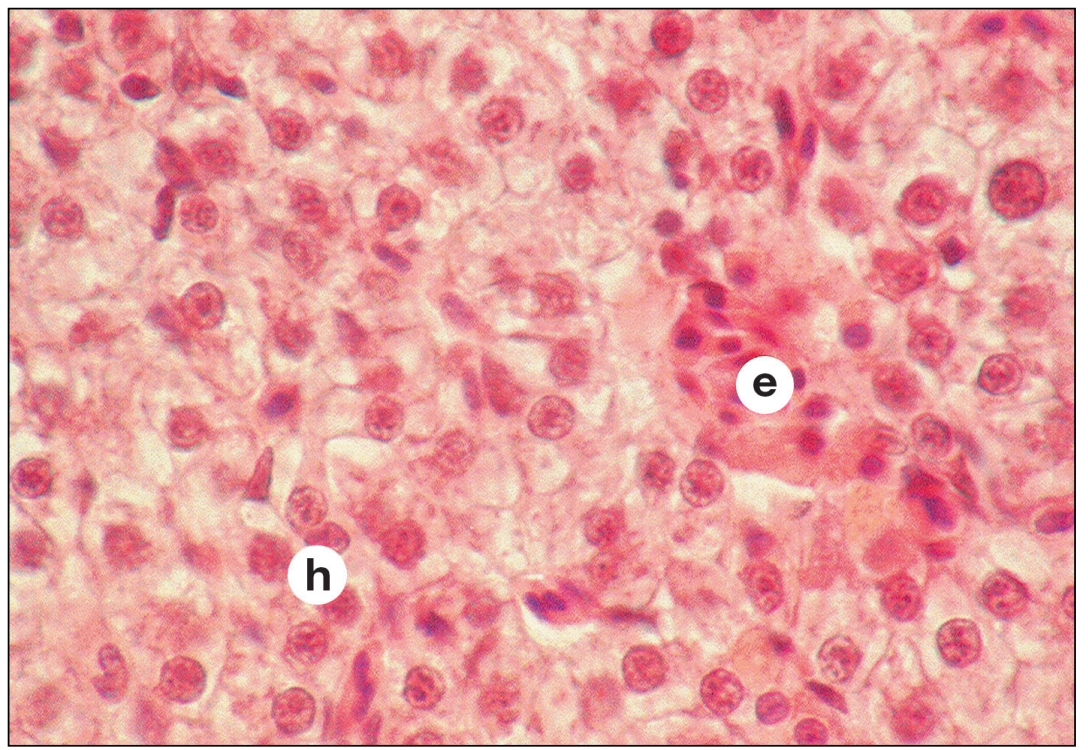

Fig. 1. Liver tissue of a control animal. Magnification $\times 100$ (h-hepatocyte, e-erythrocyte)

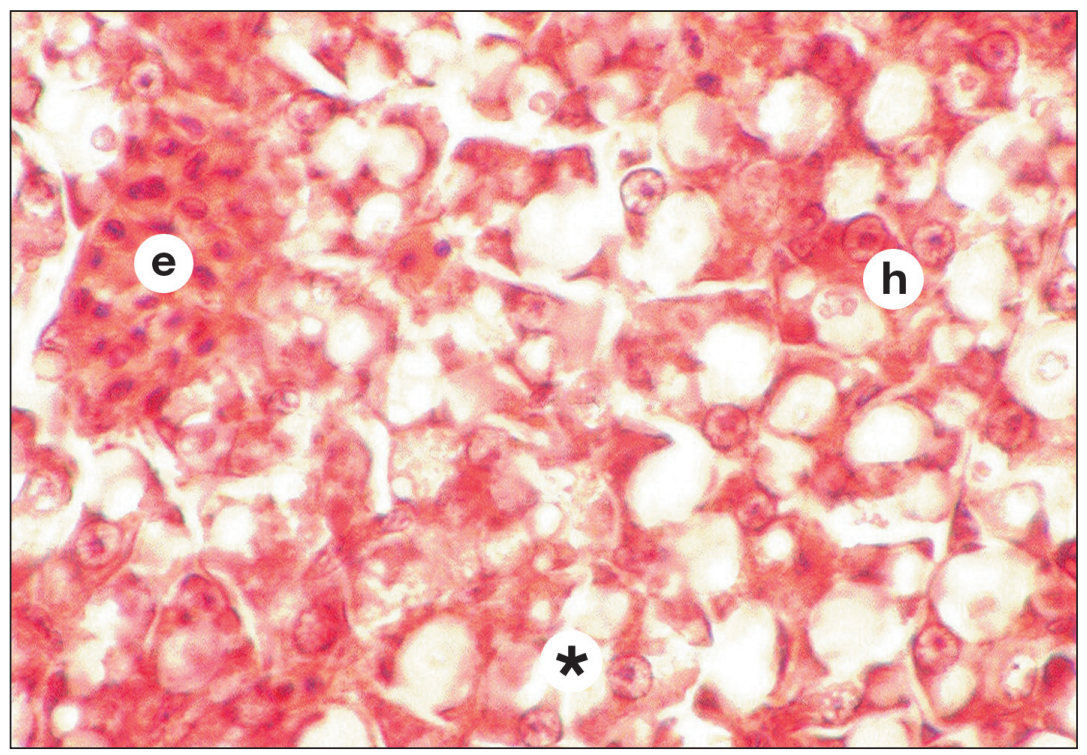

Fig. 2. Liver tissue of fish 24 hours after irradiation with a dose of $30 \mathrm{~Gy}$. Magnification $\times 100$ (h - hepatocyte, * - lipid droplets; e - erythrocyte) 


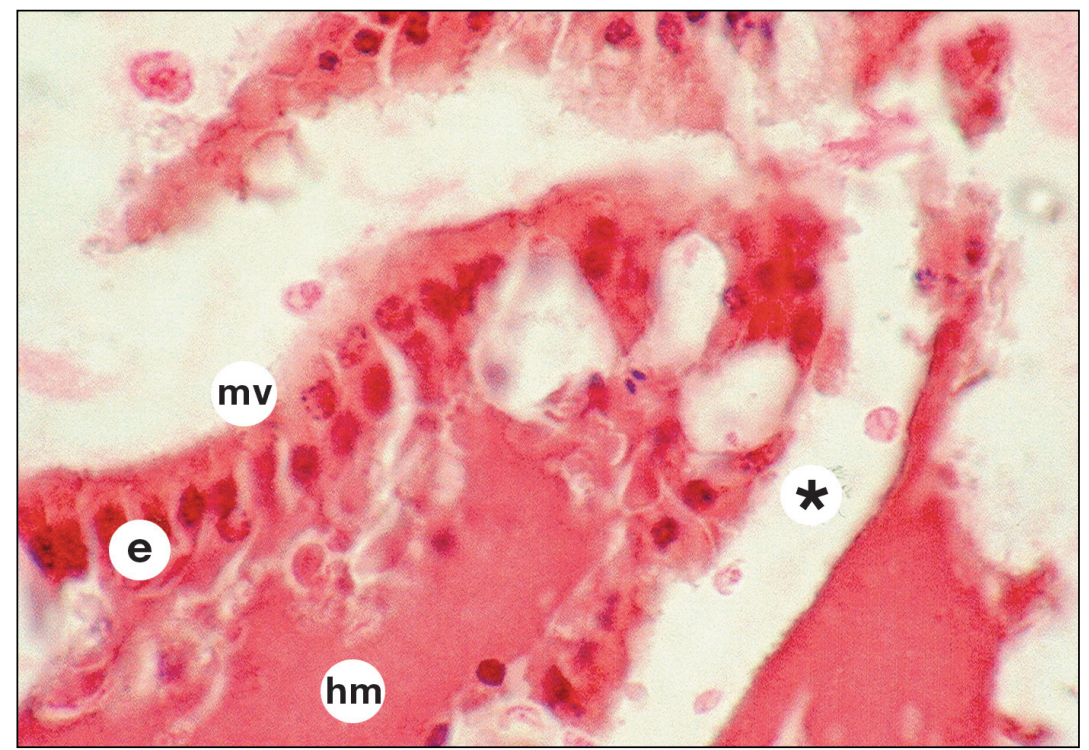

Fig. 3. Part of an enteric villus from fish irradiated with a dose of $30 \mathrm{~Gy} 24$ hours after irradiation. Magnification $\times 100$ (e - enterocyte; mv - microvilli; * - delaminated epithelium; hm homogenous material) 